\title{
A escrita espontânea de pré-escolares: o que demonstra sobre as hipóteses da escrita
}

\section{The spontaneous writing of preschoolers: what they demonstrate about the hypothesis of writing}

\section{Escritura espontánea en preescolares: lo que demostran sobre las hipótesis de la escritura}

iD Biatriz de Souza Monteiro
Instituto Federal de Ciência e Tecnologia do Ceará (IFCE); Maranguape, Ceará, Brasil -
E-mail: biatrizpedagoga@gmail.com

iD (9) Helena de Lima Marinho Rodrigues Araujo

Universidade Estadual do Ceará (UECE); Fortaleza, Ceará, Brasil

E-mail: helena.marinho@uece.br

Resumo: O presente estudo, no formato de relato de experiência, versa sobre a aquisição da escrita de pré-escolares. Sua problemática inserese nas reflexões feitas sobre a prática pedagógica da pesquisadora no contexto da escrita espontânea na sua turma de Infantil 5 (cinco). A pergunta geradora interessa-se em saber: o que a escrita espontânea de pré-escolares revela sobre as hipóteses da escrita? Convertendo-se no objetivo de identificar as hipóteses da escrita nos esboços espontâneos dos pré-escolares, na turma de infantil 5 (cinco). Regido pela concepção qualitativa de pesquisa, a pesquisa-ação permitiu averiguar e aferir as hipóteses da escrita nos escritos espontâneos dos discentes.

Palavra-chaves: Pré-escola. Escrita espontânea. Hipóteses da escrita.

Abstract: The present study, in the format of an experience report, deals with the acquisition of writing of preschoolers. The problematic is part of 
the reflections made about the pedagogical practice of the researcher in the context of spontaneous writing in her class. The generating question focuses on: what does spontaneous writing of preschoolers expose about the hypotheses of writing? Aiming at this, to identify the hypotheses of writing in the spontaneous drafts of the preschoolers, in the kindergarten class. Governed by the qualitative conception of research, the action research allowed us to ascertain and measure the hypothesis of writing in the spontaneous writing of the students.

Keywords: Preschoolers. Kindergarten. Spontaneous writing. Writing hypotheses.

Resumén: El presente estudio, en forma de narración de experiencia, se ocupa de la adquisición de la escritura de los preescolares. Su problema es parte de las reflexiones realizadas sobre la práctica pedagógica de la investigadora en el contexto de la escritura espontánea en su clase de educación infantil de niños de cinco años. La pregunta generadora se centra en saber: ¿qué expone la escritura espontánea de los preescolares sobre las hipótesis de la escritura? Con este objetivo, identificar las hipótesis de la escritura en los esbozos espontáneos de los preescolares, en la clase infantil 5. Regido por la concepción cualitativa de la investigación, la investigación acción permitió averiguar y cotejar las hipótesis de la escritura en los escritos espontáneos de los estudiantes.

Palabras clave: Preescolar. Escritura espontánea. Hipótesis de la escritura.

Submetido em 8 de fevereiro de 2021.

Aceito em 04 de abril de 2021.

Publicado em 11 de agosto de 2021. 


\section{Delimitando o estudo}

O presente estudo versa sobre a aquisição da escrita por préescolares. Entende-se a escrita, nesta pesquisa, sob a perspectiva da Psicogênese, ou seja, é concebida como contínua e sequencial, ou em fases, como as chamadas hipóteses da escrita. Compreendendo a função social da escrita, percebe-se que esta não está deslocada das vivências dos sujeitos, mas é observada em seus mais diversos espaços sociais. Dessa forma, é pretensão deste estudo discutir, sob essa ótica, o desenvolvimento do sistema escrito em crianças da pré-escola a partir da sua espontaneidade, isto é, compreender a escrita de crianças da pré-escola a partir do que já rascunham em seus esboços no cotidiano escolar.

Ao observar os exercícios de escrita espontânea, percebeu-se que se pode aferir em que fase do desenvolvimento da escrita está a criança. À vista disso, e percebendo esses aspectos em sala de aula, emergiu o interesse em transformar o que nos inquieta em problemática a ser analisada em formato de pesquisa científica, tecendo tais apontamentos sob a concepção de alfabetizar letrando de Soares (2012). Sabe-se da relevância da prática de alfabetizar letrando para o professor, principalmente na perspectiva de direcionar o fazer docente, com ênfase no desenvolvimento de aprendizagens significativas, garantindo o direito à educação, ao pleno desenvolvimento das crianças e promovendo a discussão em âmbitos maiores.

Desse modo, a partir de práticas pedagógicas na pré-escola, em que se percebeu a possibilidade de exercícios de escrita espontânea na turma de Infantil 5 (cinco), formulamos como pergunta de partida a seguinte questão: o que a escrita espontânea de pré-escolares expõe sobre as hipóteses da escrita? Por seu aspecto geral, desdobra-se em perguntas auxiliares, como: a préescola sempre possibilita práticas de escrita? Como a Psicogênese pode direcionar esse caminho a partir dos construtos da teoria de Piaget? Existem alfabetização e letramento na Educação Infantil? O 
que é leitura e escrita para a perspectiva da Psicogênese? E como são delimitadas, para a Educação Infantil, as questões referentes ao desenvolvimento da escrita? Quais são os estágios que a perpassa? Todas essas perguntas são respondidas nessa escrita espontânea? Tais questionamentos serão respondidos no decorrer deste texto.

Por essa razão, os questionamentos supracitados incorparamse às pretensões deste estudo, transformando-se, dessa forma, no objetivo geral de identificar as hipóteses da escrita em esboços espontâneos e pré-escolares na turma de Infantil 5 de uma escola de Educação Infantil e Fundamental da rede pública municipal de ensino de Fortaleza-CE. Assim, os objetivos específicos são: descrever os construtos da teoria de Piaget e suas contribuições para o desenvolvimento da escrita, bem como os desdobramentos de sua teoria à vista de Ferreiro e Teberosky (1999) no que concerne à escrita; elencar os estágios da escrita segundo a Psicogênese; e conhecer se há, nos documentos nacionais da Educação Infantil, habilidades destinadas ao desenvolvimento da escrita.

A seguir, a base teórica deste estudo, constituída pela perspectiva da Psicogênese, foi formulada na seguinte sequência: primeiro, situa-se o caminho metodológico que descreve os métodos e técnicas empregados neste estudo; em segundo, as descrições da literatura já existentes; em terceiro, os achados em campo e, por fim, algumas conclusões.

\section{Procedimentos metodológicos}

A presente pesquisa é concebida sob abordagem qualitativa. Quanto à tipologia, caracteriza-se como pesquisa-ação. Conforme Bastos (2005, p. 35), essa tipologia integra o pesquisador no processo "[...] e seu objetivo é agir sobre a realidade." Quanto aos seus objetivos, tem abordagem de natureza descritiva e explicativa.

O estudo teve sua base teórica construída a partir de diversas fontes. Para isso, utilizamos artigos, livros e documentos de autores 
que contextualizam a temática do processo de desenvolvimento cognitivo a partir de Piaget, que são: Davis e Oliveira (1994); Goulart (2015); e Kramer (2004). No tocante à temática do processo de alfabetização e letramento na Educação Infantil, os autores: Soares (2012); Kishimoto (2010); e Lucas (2008). Por fim, no que tange à leitura e a escrita: Ferreiro (2010) e Pinheiro (2019).

Em campo, foi aplicado o instrumental de pesquisa e coletados os achados em uma turma de Infantil 5 (cinco) de 22 alunos. A amostragem ficou delimitada em 17 alunos da turma devido à frequência irregular dos demais. O lócus foi a instituição municipal de Ensino Infantil e Fundamental, localizada na cidade de Fortaleza no Ceará, ambiente de trabalho da pesquisadora.

A coleta aconteceu no período de agosto a dezembro de 2019, utilizando-se como instrumentação a observação participante da escrita espontânea e o recolhimento destas produções para apreciação. As escritas conceberam-se a partir das práticas que possibilitaram tais exercícios espontâneos e significativos para as crianças. A análise se deu a partir da perspectiva da Psicogênese, com os dados compilados na ferramenta Word e expressos por meio das fotografias, dos quadros esquemáticos e da redação de texto.

\section{Pré-escola: desdobramentos quanto à escrita espontânea}

\subsection{O desenvolvimento, a linguagem e o pensamento na perspectiva de Piaget}

Jean Piaget foi um teórico interacionista que se dedicou à investigação da estruturação do conhecimento, desde o nascimento à fase adulta, com área de formação em Biologia. Seus pensamentos circundam os aspectos do desenvolvimento biológico humano, com ênfase interacionista. Postulou, conforme Davis e Oliveira (1994, p. 37), "[...] uma concepção de desenvolvimento envolvendo 
um processo contínuo de trocas entre o organismo vivo e o meio ambiente". Assim, mediante as interações possibilitadas, dadas as fases em que se encontram os sujeitos, Piaget vislumbra que "[...] as categorias de conhecimento não são estáticas; elas mudam durante o ciclo do desenvolvimento" (GOULART, 2015, p. 143).

A Teoria da Psicologia Genética de Piaget tem como alicerce a noção de equilíbrio, que na sua concepção é o estado de adaptação diante das perturbações advindas do meio. Isso significa que frente às novas problemáticas, desafios e conhecimentos, o sujeito desequilibra e busca na relação que estabelece com o meio superar e voltar ao seu estado de repouso, no sentido de que já conseguiu compreender a problemática, vencer o desafio e assim por diante em cada fase de desenvolvimento.

Nesse processo, "[...] o desenvolvimento cognitivo deve fundir suas raízes com o crescimento biológico e os princípios básicos do primeiro devem ser encontrados entre os que têm validade para o segundo" (GOULART, 2015, p. 144). Nessa dinâmica, os equilíbrios, cognitivamente falando, vão se ajustando de acordo com as demandas do desenvolvimento físico, assim como se observa na progressão que perpassa as hipóteses da escrita, na medida em que cognitiva e linguisticamente a criança se desenvolve.

Para isso, existem mecanismos que são ativados para atingir o novo estado de equilíbrio. Conforme Goulart (2015, p. 144), "[...] os principais modos de adaptação eram a assimilação e a acomodação", ideias essas derivadas da teoria de Darwin (18091882). Sendo a assimilação o processo de atribuir significados às novas situações colocadas, o sujeito buscará nas experiências anteriores, conforme o ambiente que interage, meios de compreender a situação colocada.

Já a acomodação é compreendida como ajuste, o organismo é empurrado a se ajustar à nova situação, um momento de saber lidar com a nova demanda, por meio do processo de já tê-lo assimilado. Embora distintos, ambos os mecanismos, assimilação e acomodação, acontecem simultaneamente, enquanto uma busca 
na experiência a compreensão, o outro recebe e ajusta essa compreensão junto ao organismo, chegando, com isso, ao seu estado de equilíbrio (DAVIS; OLIVEIRA, 1994).

Nessa perspectiva, conforme Davis e Oliveira (1994, p. 39), “[...] Piaget definiu o desenvolvimento como sendo um processo de equilibrações sucessivas". Apesar de contínuo, perpassa distintas fases, passos ou momentos. Cada um desses se constitui e é marcado por um momento de desenvolvimento, por meio do qual o sujeito constrói as estruturas cognitivas. Esse “[...] desenvolvimento cognitivo é processo sequencial marcado por etapas caracterizadas por estruturas mentais diferenciadas" (GOULART, 2015, p. 163). Piaget enquadrou o desenvolvimento em quatro etapas distintas, a saber: a Sensoriomotora, Pré-operatória, Operatória-concreta e Operatória-formal.

A primeira etapa, Sensoriomotora, se inicia no nascimento e se estende até os dois anos de idade, momento em que o sujeito age mediante as estimulações com o meio. Esse mundo que rodeia a criança é difundido por meio da percepção e dos movimentos, como o toque e o mexer dos olhos, por exemplo (DAVIS; OLIVEIRA, 1994).

Nesse movimento, a criança vai se superando e avançando, e se começa a construir as noções de espaço, tempo e causalidade que serão a marca para o início da nova etapa: a Pré-operatória, que se amplia dos 2 aos 7 anos de idade. A característica inicial da nova fase é o aparecimento da linguagem oral que dará a possibilidade, com o que já foi construído na fase anterior, da construção de esquemas interiores, ou simbólicos, a partir dos quais a criança formula conceitos preexistentes a respeito de alguma coisa.

A transição para a próxima etapa, Operatório-concreto, dáse pela estruturação do pensamento lógico e objetivo, e as ações anteriormente acomodadas ganham reversibilidade, uma vez que as estruturas permitem, de forma concreta, as idas e vindas ao ponto de partida. Característica marcante do pensamento nessa etapa é o raciocínio. Desse modo, para assimilar as situações que 
necessitam de exemplificação concreta, os indivíduos precisam de materialidade, pois as estruturas não conseguem ainda assimilar a partir de pressupostos e/ou hipóteses com base em proposições ou enunciados.

Essas últimas características supracitadas são marcantes no estágio seguinte: Operatório formal. Nele, o pensamento se desprende e se torna livre das ilustrações materiais, podendo então ocorrer a partir das hipóteses propostas com base apenas nas preposições. A criança pode construir de forma lógica e concreta, mesmo que o exemplo dado não seja real ou compatível com a realidade. Dessa forma, consegue abstrair a situação e resolvêla sem complicações ou limitações. Característica marcante do pensamento nesta etapa é o raciocínio hipotético-dedutivo, que dará permissão ao adolescente, agora, para estender o seu pensamento ao infinito (DAVIS; OLIVEIRA, 1994).

Nessa perspectiva, Piaget acrescenta que "[...] as etapas do desenvolvimento do pensamento são, ao mesmo tempo, contínuas e descontínuas" (DAVIS; OLIVEIRA, 1994, p. 45). Contínuas porque dão continuidade às anteriores, incrementando-as. Descontínuas porque não é simplesmente dar continuidade à etapa anterior uma vez que transformações drásticas acontecem na estruturação do pensamento dos sujeitos. Assim, percebe-se que o modelo piagetiano é marcado, sobretudo, pela maturação, pois apresenta certas características psicológicas em uma mesma faixa etária. Isso não quer dizer que todas as crianças sejam iguais ou tenham o mesmo desenvolvimento, o que parece contraditório, mas não é.

Em síntese, desenvolvimento, para Piaget, é um processo contínuo e sequencial, marcado por características distintas, porém complementares, que não se reduz apenas à continuação de um momento para o outro, mas de transformações que necessitam das construções anteriores e são distintas, marcando, com isso, novos e significativos passos, como também novos e drásticos momentos no que concerne ao desenvolvimento. Kramer (2004, p. 120) acrescenta ser "[...] o momento de desenvolvimento da criança que determina que ela internalize ou não aquele dado 
que vem de fora". Nesse sentido, Goulart (2015, p. 163) acrescenta que o processo de desenvolvimento cognitivo "[...] depende da estrutura mental que a criança apresenta naquele momento". Ou seja, um caminho que será relativo, dependendo, com isso, da etapa de desenvolvimento vivenciada pelo sujeito.

\subsection{Alfabetização e letramento na Educação Infantil?}

Antes de entrar diretamente na resposta à indagação, faz-se necessário conceituar os termos "alfabetização" e "letramento" para que as tensões e conceitos pré-concebidos suavizem em torno da tão polêmica questão que é a alfabetização e o letramento na Educação Infantil. Senso assim, esses conceitos, inicialmente, por sua escrita já indicam os seus significados, uma vez que essas palavras já fazem parte do cotidiano docente. Entretanto, faz-se necessário refletir sobre os seus sentidos, de modo que a semântica dos termos possa clarear nossa problemática.

Em relação ao termo "alfabetização", para não haver conflitos quanto a sua semântica, é preciso conceituar as suas derivações, uma vez que, por mais parecidos que sejam, não indicam a mesma coisa, como pensam alguns. Nesse sentido, Soares (2012) elucida de forma sucinta essa questão, a começar pelo termo "analfabeto", que se trata dos sujeitos privados do alfabeto, em outras palavras, que não sabem ler e escrever. $O$ "analfabetismo" é a condição dos que, como anteriormente dito, estão privados do ato da leitura e da escrita. Já "alfabetizar" é o processo de tornar o sujeito apto a ler e a escrever. E, por fim, "alfabetização" diz respeito à ação anterior, de alfabetizar, ou seja, tornar esse sujeito alfabetizado.

O termo "alfabetização" está ligado ao ato ou à competência de saber ler e escrever, do contato com o universo da leitura e, com isso, da escrita. Entretanto, com os avanços da sociedade e com os novos fenômenos em expansão, como o combate cada vez mais assíduo ao analfabetismo, novos termos e palavras surgem constantemente. Os avanços da tecnologia também fizeram com 
que novas habilidades fossem requeridas, já que a interação com essa nova realidade digital exige competências para além do reconhecimento do sistema escrito e sua reprodução, pois apenas ler e escrever não são suficientes na sociedade atual (PINHEIRO, 2019). Nesse novo contexto, é necessário saber o que esse sujeito é capaz de fazer, uma vez apto dessas habilidades. Assim,

\begin{abstract}
À medida que o analfabetismo vai sendo superado, que um número cada vez maior de pessoas aprende a ler e a escrever, e à medida que, concomitantemente, a sociedade vai se tornando cada vez mais centrada na escrita (cada vez mais grafocêntrica), um novo fenômeno se evidencia: não basta apenas aprender a ler e escrever. As pessoas se alfabetizam, aprendem a ler e escrever, mas não necessariamente incorporam a prática da leitura e da escrita, não necessariamente adquirem competência para usar a leitura e a escrita, para envolver-se com as práticas sociais de escrita (SOARES, 2012, p. 46, grifo da autora).
\end{abstract}

Nessa perspectiva, surgiu o conceito de "letramento", que embora não possua ainda significado nos dicionários brasileiros, vem sendo discutido e aplicado, principalmente no cotidiano docente. Conforme Soares (2012), o termo "letramento" é derivado da palavra inglesa literacy, que em sua tradução remete à condição do sujeito que, já apto a ler e a escrever, realiza socialmente com as habilidades, isto é, uma vez apto a essas habilidades, usa-as em seu contexto social, atua sobre ela ou atua sobre o contexto social, utilizando-as em seu dia a dia. Soares (2012, p. 17) completa afirmando que "[...] implícita nesse conceito está a ideia de que a escrita traz consequências sociais, culturais, políticas, econômicas, cognitivas, linguísticas, quer para o grupo social em que seja introduzida, quer para o indivíduo que aprenda a usá-la".

Assim, ao pé da letra, conforme a tradução de literacy, letramento é uma condição resultante do processo de aprendizagem da leitura e da escrita, uma vez que no seu contexto social o indivíduo usa socialmente essas habilidades. Dessa forma, internaliza e 
faz o uso do sistema escrito que lê e escreve. Corroborando, Soares (2012, p. 44) diz que letramento "[...] é o estado ou condição de quem se envolve nas numerosas e variadas práticas sociais de leitura e escrita". Em outras palavras, de posse dessas habilidades, o indivíduo atua de forma significativa em seu cotidiano em sociedade, tornando-se capaz de utilizar as diferentes ferramentas que o rodeia, pois agora, além de reconhecer o sistema escrito, opera sobre e com ele.

Desse modo, a alfabetização é compreendida como o processo de aquisição da leitura e da escrita, e letramento como condição que o sujeito assume frente ao uso social da língua falada e escrita, a partir do qual adquire e faz o uso socialmente. Para Soares (2012, p. 47), o ideal é que tivessem que: "[...] alfabetizar e letrar como duas ações distintas, mas não inseparáveis, ao contrário: o ideal seria alfabetizar letrando, ou seja: ensinar a ler e a escrever no contexto das práticas sociais da leitura e da escrita, de modo que o indivíduo se tornasse, ao mesmo tempo, alfabetizado e letrado". Segundo a autora, fala-se, portanto, de uma aprendizagem significativa, a partir da qual se aprende para atuar, conforme os objetivos educacionais, ativamente na sociedade a qual se pertence.

E a alfabetização e o letramento na Educação Infantil? A pré-escola, como já discutido neste estudo, nem sempre foi um espaço de ensino tido como formal. Até algumas décadas, segundo Kishimoto (2010), era um momento de preparar as crianças para a alfabetização; em outras palavras, era o momento em que desenvolveriam bem as noções de espaço, tempo, lateralidade, dentre outras competências que se julgam necessárias para a aprendizagem da leitura e da escrita. Com a chegada do letramento, no contexto de seu uso, mesmo não alfabetizadas, as crianças mostram que fazem uso da leitura e da escrita como prática social. Mas como assim? Conforme Kishimoto (2010, p. 24), “[...] letramento/literacia como prática social implica reconhecer a diversidade de suas manifestações em diferentes áreas da linguagem: falada, escrita, visual, a combinação de várias modalidades e em sua forma crítica". 
Isso quer dizer que as crianças da pré-escola, desde o âmbito familiar, vêm sendo inicialmente inseridas no contexto letrado, isto é, têm contato com a cultura escrita e manifestam leitura de imagens e identificação do código escrito, claro que dentro de suas limitações, como: nos rótulos, nas imagens, nas propagandas, nos desenhos midiáticos em seus mais variados formatos, dentre outros. Lucas (2008) esclarece que embora sejam processos distintos, os mesmos caminham juntos; isso quer dizer que são interdependentes, sendo essa uma condição que sistematiza a prática docente e provém a mesma de intencionalidade. Assim, a autora segue afirmando que é função da Educação Infantil enriquecer o letramento e trabalhar dentro das possibilidades das crianças a alfabetização, reconhecendo que esse processo exige muito mais do que a simples tarefa de desvendar e reproduzir os sistemas escritos. Leitura e escrita e seu uso socialmente são processos possíveis na Educação Infantil, porém requerem aprofundamento docente para a sua prática efetiva e significativa.

O documento normativo, Base Nacional Comum Curricular BNCC (BRASIL, 2018), que rege o conjunto orgânico e progressivo das aprendizagens essenciais que devem ser desenvolvidas em todas as etapas e ofertadas a todos os alunos da educação básica, reafirma os apontamentos de Lucas (2008). A base integra em um documento oficial a Educação Infantil às demais etapas da educação básica, fortalecendo sua obrigatoriedade e importância. Dentro de sua perspectiva de educar e cuidar, a Educação Infantil fortalece os seis direitos de aprendizagem da etapa: conviver, brincar, participar, explorar, expressar e conhecerse. Esses direitos são explorados por meio de seus cinco campos de experiências, dos quais destacamos o campo: Escuta, fala, pensamento e imaginação. A partir da visão etária cada campo comporta conjuntos de habilidades.

Embora os demais fortaleçam os aspectos motores para escrita, a este campo responsabilizamos pela desenvoltura inicial com o letramento e alfabetização. Suas habilidades, na faixa etária que corresponde à pré-escola (4 a 5 anos e 11 meses), direcionam 
o fazer docente ao trabalho com a diversidade de gêneros textuais, como elemento que irá possibilitar a alargamento do convívio com a cultura escrita, o que desembocará na construção de hipóteses da escrita "[...] que se revelam, inicialmente, em rabiscos e garatujas e, à medida que vão conhecendo letras, em escritas espontâneas, não convencionais, mas já indicativas da compreensão da escrita como sistema de representação da língua" (BNCC, 2018, p. 42, grifo do autor).

\subsection{A leitura e a escrita}

Como já discutido, o processo de alfabetização e letramento está diretamente ligado à aquisição e desenvolvimento da leitura e da escrita. É necessário, neste momento, compreender o que é leitura e o que é escrita. Dessa forma, a leitura diz respeito ao processo de decodificação e compreensão, mas não apenas isso.

Enquanto a leitura circunda em pressupostos para sua melhor realização, a escrita depende de aspectos diversos para o seu acontecimento. Daqui em diante, neste tópico, discutiremos esses aspectos, compreensões, concepções e fases da escrita. Conforme Ferreiro (2010, p. 14): "a escrita pode ser considerada como uma representação da linguagem ou como um código de transcrição gráfica das unidades sonoras". Ou melhor, a escrita se trata da ação de traduzir a fala em grafias, texto escrito, frases e letras devidamente relacionados aos sons que emitem e possuem.

Em consonância com Pinheiro (2019), o ato de escrever demanda habilidades que se referem a aspectos de ordem motora, cognitiva e social, como o esquema da Figura 1 apresenta a seguir: 


\section{Figura 1 - Aspectos necessários para o desenvolvimento da escrita}

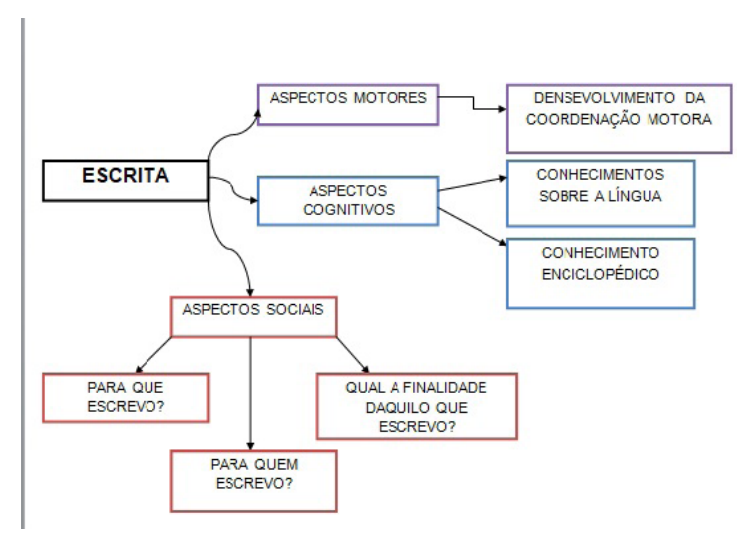

Fonte: Elaborado pelas autoras.

O primeiro aspecto a se considerar é o motor, pois está ligado à competência de desenvolver movimentos, e estes distribuídos em coordenação motora ampla e coordenação motora fina. A ampla está relacionada às atividades de vasta movimentação, como as brincadeiras de correr, andar sobre linhas, dentro/fora, pular corda, dentre outras. A motora fina, como o nome já indica, está relacionada às atividades de coordenação mais precisa, tais como: recortar, colar, cobrir tracejados, segurar corretamente o lápis, dentre outras. Esses são alguns dos exemplos de situação/ ações que contribuem para o bom desenvolvimento da escrita no aspecto destacado (PINHEIRO, 2019).

Outro aspecto é o cognitivo, que está "[...] relacionado aos conhecimentos que o autor do texto deve ter ou deve adquirir para, no ato da produção textual, eles serem acionados" (PINHEIRO, 2019, p. 69). Este também se distribui em dois: conhecimentos da língua, que são os relacionados à ortografia, gramática, vocabulário e gênero textual; e o enciclopédico, que se trata do conhecimento de mundo. Ressalta-se aqui ambos os conhecimentos, tanto aqueles exigidos pela língua, para sua produção no que se determina adequada, quanto os conhecimentos que o sujeito adquire em sua vida em sociedade, tão necessários quanto o dito formal.

Por fim, o outro aspecto a se considerar é relacionado aos aspectos sociais. A estes é necessário considerar que a escrita, 
além de depender, tem sempre uma finalidade sociocomunicativa. Isto quer dizer que é preciso considerar: Para quê escrevo? Isto é, o objetivo comunicativo do texto; Para quem escrevo? Em outras palavras, o interlocutor a que se direciona; e por fim, Qual a finalidade desta escrita? Ou melhor, a situação em que o texto acontece.

Neste processo, Ferreiro (2010) acrescenta que as crianças:

[...] trabalharam cognitivamente sobre as propriedades formais do sistema (as regras de composição dos elementos do sistema, assim como a relação entre sequências bem construídas e unidades da língua oral). Por outro, trabalharam cognitivamente sobre o modo de existências da escrita na sociedade (FERREIRO, 2010, p. 33).

Em outras palavras, as crianças elaboram modos de compreender pela forma que esboçam incialmente e se esforçam na compreensão histórica do fenômeno que é a escrita.

Ferreiro e Teberosky (1999) apontam que esses conhecimentos sobre a escrita podem ser observados por meio dos rascunhos espontâneos das crianças. Este estilo de escrita é permeado de hipóteses que as mesmas constroem sobre o processo de escrita, oferecendo ao docente, assim, uma multiplicidade de reflexões. Por esta razão, é necessário estar atento ao ato, pois como acrescenta Ferreiro (2010):

Quando uma criança escreve tal como acredita que poderia ou deveria escrever certo conjunto de palavras, está oferecendo um valiosíssimo documento que necessita ser interpretado para poder ser avaliado. Essas escritas infantis têm sido consideradas, displicentemente, como garatujas, "puro jogo", o resultado de fazer "como se" soubesse escrever. Aprender a lê-las - isto é, a interpretá-las - é um longo aprendizado que requer uma atitude teórica definida (FERREIRO, 2010, p. 20). 
Para tanto, é necessário saber que, embora sejam fases distintas e parecidas, elas caminham em uma ordem crescente que não só evolui de uma hipótese para a outra, mas que perpassa transformações cognitivas, frutos de constantes problematizações elaboradas pelos docentes que caminham com o objetivo de alfabetizar e letrar os seus alunos, compreendendo e refletindo sobre o processo. Mas, para isso, é necessário o entendimento postulado por Ferreiro e Teberosky (1999) sobre os três grandes períodos permeados das mais variadas subdivisões que perpassam a evolução do processo de escrita.

Ferreiro (2010) divide os três períodos da seguinte forma: modo de representação icônico e o não icônico; a construção de formas de diferenciação (eixos qualitativos e quantitativos) e a fonetização da escrita. Destes, como já mencionado, terão muitas outras divisões, que serão aqui expostas mais detalhadamente no espaço destinado à análise e discussão.

\section{0 que diz a escrita espontânea sobre as hipóteses da escrita}

Neste espaço serão apresentados os dados coletados durante as observações na turma, bem como o respaldo teórico que permitirá a identificação das hipóteses da escrita.

\subsection{Perfil dos observados}

Quadro 1 - Perfil dos discentes

\begin{tabular}{|c|c|c|c|}
\hline Alunos & Idade & Turma & Turno \\
\hline 10 Meninas & Todas 5 anos & Infantil 5 & Manhã \\
\hline 7 Meninos & Todos 5 anos & Infantil 5 & Manhã \\
\hline
\end{tabular}

Fonte: Dados da pesquisa. 
Conforme se pode observar, ao todo se têm 17 discentes como sujeitos da pesquisa, dentre os quais 10 são meninas e 7 são meninos. Todos com idade de cinco anos e alunos da turma do Infantil 5 no turno da manhã. A turma é mista com relação à aprendizagem. Entende-se que cada um tem o seu tempo, e por essa razão se torna fundamental interpretar e compreender os seus escritos, pois só por meio desses diagnósticos é que se pode realizar um trabalho mais efetivo no sentido de trabalhar de acordo com o que se identificou. Para esse efeito, é necessário que se respeite o tempo e se trabalhe dentro dos limites de cada aluno.

\subsection{Descrição dos exercícios de escrita espontânea}

Este espaço foi destinado à descrição dos exercícios de escrita espontânea dos discentes e à análise e identificação das hipóteses apontadas por meio dos seus esboços. Dessa forma, identificamos os observados da Criança 1, Criança 2, e assim por diante, até a Criança 17. A descrição se deu da seguinte forma: tendo em vista o comando, será aqui exposto, de forma expressa, o que o discente esboçou espontaneamente, seguido do formato de redação de texto expresso na discussão, além da hipótese de escrita e o contexto teórico que a confirme, bem como a descrição dos exercícios que foram solicitados aos discentes.

Assim, dividiremos os níveis de escrita em três grandes períodos, que se subdividem em variados níveis, conforme a classificação feita por Ferreiro e Teberosky (1999), a iniciar com icônico e não icônico: formas de diferenciação que envolve os eixos quantitativos e qualitativos e fonetização da escrita. As construções das crianças são frutos de um trabalho sensível e atento, voltado às práticas de alfabetização e letramento, desde que enxergada essa possibilidade pela docente. Assim, conforme Ferreiro (2010): 
Em vez de nos perguntarmos se "devemos ou não devemos ensinar", temos de nos preocupar em DAR ÀS CRIANÇAS OCASIÕES DE APRENDER. A língua escrita é muito mais que um conjunto de formas gráficas. É um modo de a língua existir, é um objeto social, é parte de nosso patrimônio cultural (FERREIRO, 2010, p. 99, grifo da autora).

Não se trata de escolher ensinar, mas de perceber a prontidão e a necessidade do contato com as mais variadas formas de interação com a linguagem, entre elas a escrita. Foi assim que aconteceu durante o projeto "Meio Ambiente", no qual existiram subdivisões. Nesses desdobramentos do projeto, outras temáticas pertinentes ao tema iam surgindo, como, por exemplo: as árvores - as árvores frutíferas e alimentação saudável.

$\mathrm{Na}$ alimentação se falou muito nas frutas e na sua contribuição à nossa saúde. A partir disso, na roda de conversa as frutas foram exploradas, os seus tipos, o paladar de algumas, até se chegar às frutas preferidas dos alunos. Durante toda uma semana se trabalhou essa temática. No último dia, conforme a exploração, cada um recebeu metade de uma folha $\mathrm{A} 4$ e todos foram convidados a desenharem pelo menos três de suas frutas favoritas, e ao lado de cada desenho foi solicitado que deveriam escrever o nome da fruta como soubessem.

Havia apenas duas regras. Qual o intuito das regras? As crianças da pré-escola, conforme observado, têm medo de escrever, tudo por conta de uma cultura de correção grosseira da escrita que não é convencional, não se enquadrando na chamada correta/formal. Então, para não haver cópias entre os colegas e a escrita fosse de fato espontânea, duas "regrinhas" foram delimitadas: não deixar o colega ver e escrever livre como um passarinho. Mediante a delimitação da atividade, chegou-se ao presente resultado: 


\section{Figura 2 - Criança 1}

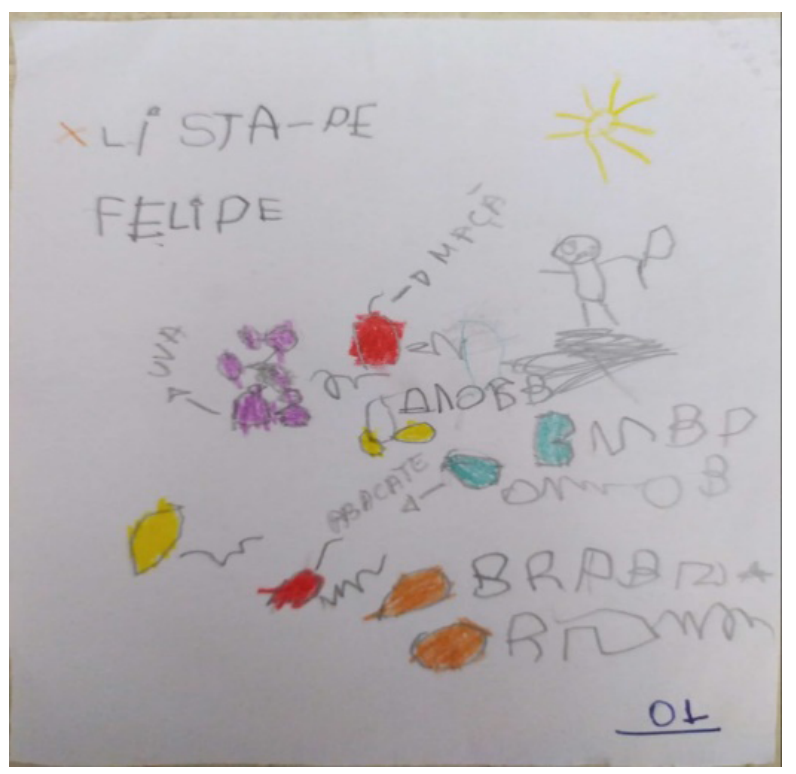

Fonte: Dados da pesquisa.

Conforme sua escrita, a Criança 1 está naquilo que se chama aqui de transição da fase um, entre os dois níveis, icônico e não icônico. Especificando, Figueiredo et al. (2009) aponta essa fase como o momento em que se representa a escrita por meio do desenho e, como a criança está na passagem, ela já mistura símbolos, letras e rabiscos. Está em fase inicial e já demonstra que desenho é diferente de letra, como se observou em sala durante a construção.

A Criança 1 é uma das que mais se recusava a escrever, embora a atividade fosse livre, ela usava de um esforço muito grande nas representações, e o que Ihe ajudava era o incentivo à produção cada vez mais livre. A dificuldade não se centrava na atividade em si, mas na transição de fases que estava the causando desequilíbrios necessários. Segundo a observação, a criança em questão se encontra na hipótese pré-silábica, com as características do primeiro período, classificada por Soares (2007) como hipótese garatuja, na qual a criança imita a escrita mesclando letras e símbolos. 
Figura 3 - Criança 2

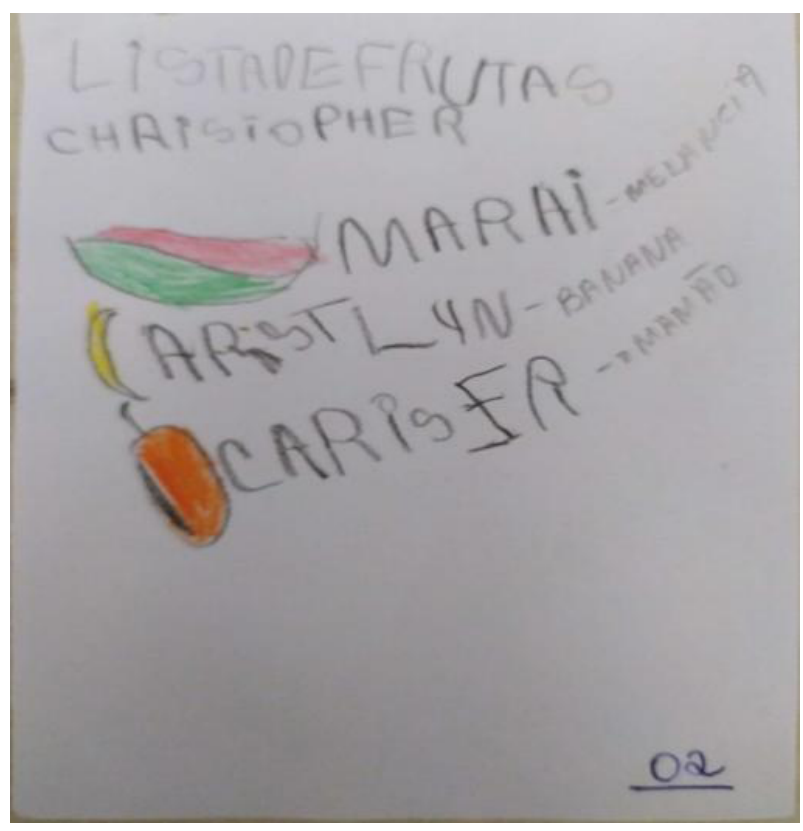

Fonte: Dados da pesquisa.

A Criança 2 está formulando suposições distintas do período inicial, mas ainda presente na hipótese pré-silábica. O que se pode apontar é: a criança já sabe que para escrever são necessárias letras e que estas precisam de uma quantidade mínima, característica marcante do eixo quantitativo, conforme Zorzi (2003). Porém, e em consonância com a visão de Soares (2007), classifica-se, também, essa hipótese como um momento no qual a criança já conhece as letras, mas o uso mostra que não associa fala e escrita, ou seja, não há ainda articulação com a sonorização, conforme o quadro a seguir, que tem o objetivo de sintetizar a representação feita pela Criança 2.

\section{Quadro 2 - Quadro-síntese Criança 2}

\begin{tabular}{|c|c|}
\hline Frutas favoritas & Como escreveu: \\
\hline MELANCIA & MARHI \\
\hline BANANA & ARSTLYN \\
\hline MAMÃO & CARISER \\
\hline
\end{tabular}

Fonte: Dados da pesquisa. 


\section{Figura 4 - Criança 3}

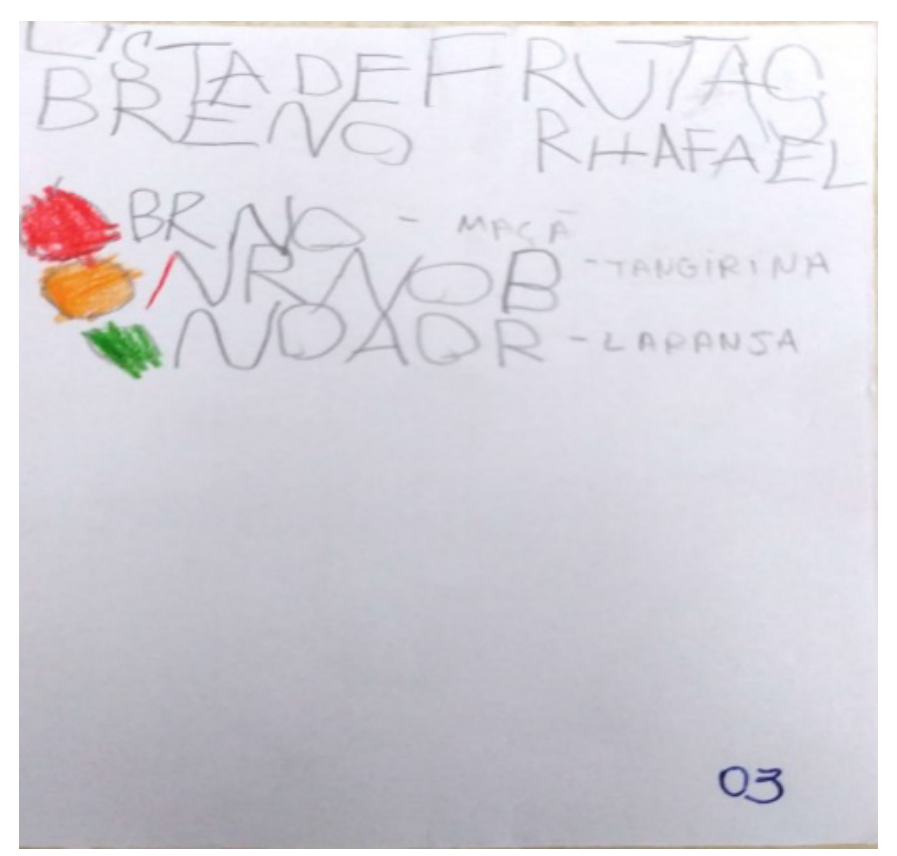

Fonte: Dados da pesquisa.

A Criança 3 demonstra os mesmos conhecimentos da Criança 2. Sua hipótese é pré-silábica, conforme a classificação de Soares (2007), pois representa a palavra com letras, sem correspondências entre sons, ou seja, não articula também fala e escrita. Porém, há outro fator muito comum nessa fase inicial entre pré-escolares: o contato inicial com a escrita é com seus nomes, uma vez que costumam usar esse repertório de letras na escrita das palavras que desejaram escrever. A Figura 2 é um exemplo bem claro disso.

Quadro 3 - Quadro-síntese da Criança 3

\begin{tabular}{|c|c|}
\hline Frutas favoritas & Como escreveu: \\
\hline MAÇÃ & BRNO \\
\hline TANGERINA & NRNOB \\
\hline LARANJA & NOAOR \\
\hline
\end{tabular}

Fonte: Dados da pesquisa. 
Conforme o quadro-síntese da Criança 3, e ainda dentro da perspectiva do eixo quantitativo, de acordo com Figueiredo et al. (2009), o aluno julga necessário uma quantidade mínima e máxima de letras, o que demonstra não ser possível, em sua concepção, ler palavras escritas por uma ou duas letras, conforme se pode observar no quadro-síntese da Criança 4.

Figura 5 - Criança 4

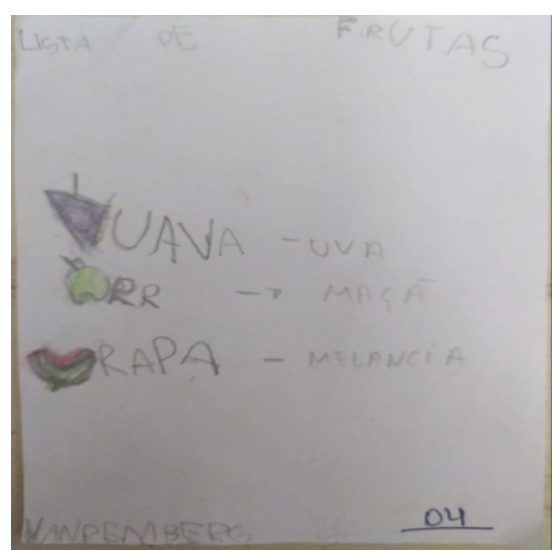

Fonte: Dados da pesquisa.

A fala da criança se inicia como alerta de Ferreiro (2010, p. 27): “[...] a coordenação dos dois modos de diferenciação (quantitativo e qualitativo) é tão difícil aqui como em qualquer outro domínio da atividade cognitiva". Os conflitos de transição e consolidação das hipóteses são complexos uma vez que as características podem ou não ser superadas. É importante lembrar que cada sujeito tem seu estilo de escrita e as crianças se apoiam nas suposições anteriores para prosseguirem. Dessa forma, podem se confundir na interpretação.

\section{Quadro 4 - Quadro-síntese da Criança 4}

\begin{tabular}{|c|c|}
\hline FRUTAS FAVORITAS & COMO ESCREVEU: \\
\hline UVA & UAVA \\
\hline MAÇÃ & RR \\
\hline MELANCIA & RAPA \\
\hline
\end{tabular}

Fonte: Dados da pesquisa. 
O exemplo anterior mostra a palavra "UVA" escrita quase que corretamente. Já a palavra "MAÇÃ" é representada com duas letras. Neste caso, já se apresentam avanços nas suposições, pois a Criança 4 percebe dois sons e os representa com duas letras, que embora não tenham correspondência com o som da palavra, sinaliza uma associação da fala com a escrita, utilizando uma letra para cada som da palavra. Conforme Soares (2012), essas são marcas típicas da hipótese silábica sem valor sonoro.

\section{Figura 6 - Criança 5}

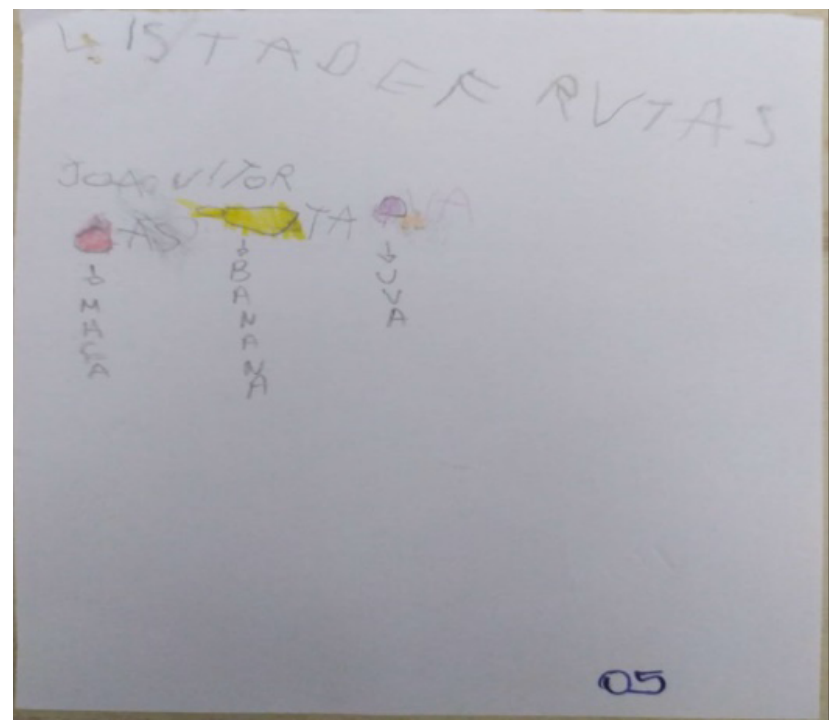

Fonte: Dados da pesquisa.

A Criança 5 demonstra, por meio de sua escrita espontânea, alguns conflitos transitórios. Inicialmente, pode parecer contraditório, por isso é importante conhecer a turma e identificar não só nesse exercício, mas na observação diária as presunções que os alunos constroem. As palavras "MAÇÃ" e "UVA" correspondem à hipótese silábica em transição para a silábico-alfabética. Por quê? Porque as letras representadas correspondem aos sons dos fonemas. Porém, por ser um período transitório, ela escreveu duas com duas letras, representando hora a quantidade de sílaba $(\mathrm{A}=$ $M A-S=(c A)$, e outra o som e a correspondência com a palavra $(V A=U V A)$. 


\section{Quadro 5 - Quadro-síntese da Criança 5}

\begin{tabular}{|c|c|}
\hline Frutas favoritas & Como escreveu: \\
\hline MAÇÃ & AS \\
\hline BANANA & TA \\
\hline UVA & VA \\
\hline
\end{tabular}

Fonte: Dados da pesquisa.

Nessa construção se pensou que a terceira palavra também tivesse apenas duas letras, embora o som não correspondesse. Nesse período, segundo Figueiredo et al. (2009, p. 11), o “[...] símbolo gráfico representa um som na fala [...] e percebe a sílaba como unidade de som das palavras [...]". E, com isso, já se demonstra um inicial conhecimento e correspondência entre fala e escrita.

Figura 7 - Criança 6

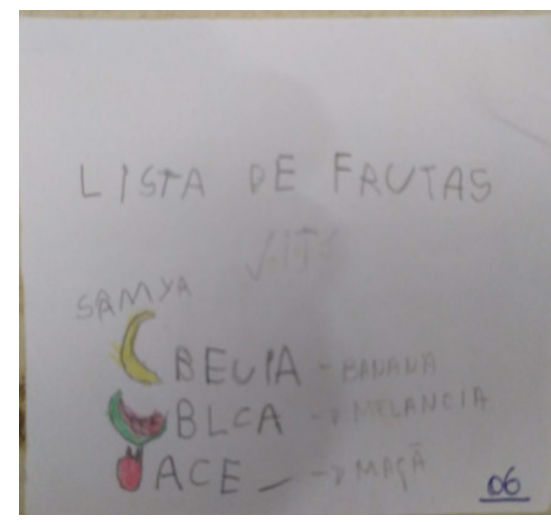

Fonte: Dados da pesquisa.

As hipóteses da Criança 6 são clássicas para a fase présilábica. De acordo com Figueiredo et al. (2009, p. 9), o período “[...] caracteriza-se pela construção de modos de diferenciação entre o encadeamento das letras". Tendo como parâmetro os eixos quantitativos e qualitativos, no caso dessa fase, a criança utiliza ambos os eixos, pois entende que nomes de coisas diferentes são escritos de formas distintas. Utiliza o critério de variedade das letras e quantidade mínima, bem como a posição das letras, compreendendo que é não permitido repetir a mesma letra na palavra, como se pode observar no Quadro 7. 


\section{Quadro 6 - Quadro-síntese da Criança 6}

\begin{tabular}{|c|c|}
\hline Frutas favoritas & Como escreveu: \\
\hline BANANA & BEUIA \\
\hline MELANCIA & BLCA \\
\hline MAÇÃ & ACE \\
\hline
\end{tabular}

Fonte: Dados da pesquisa.

Figura 8 - Criança 7

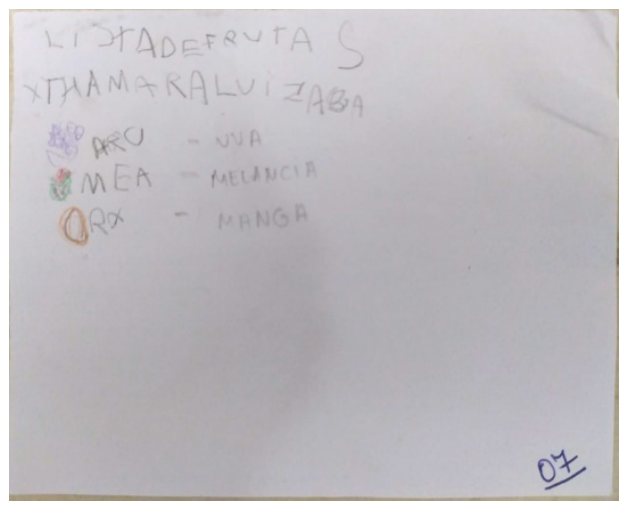

Fonte: Dados da pesquisa.

A Criança 7 está na hipótese de transição do silábico sem valor sonoro para o com valor sonoro, conforme Soares (2007). Ela representa a palavra "UVA" com três letras, ou seja, durante as vivências e comentários em sala de aula, lembrou-se dos estudos e da correção da escrita da palavra ("UVA" tem três letras) e, embora a sua escrita não corresponda, escreveu "UVA" do jeito que julga correto. Perceba que a mesma tem os dois sons da palavra (ARU), escrita ao contrário, "A" no início e o " $U$ " no final.

\section{Quadro 7 - Quadro-síntese da Criança 7}

\begin{tabular}{|c|c|}
\hline Frutas favoritas & Como escreveu: \\
\hline UVA & ARU \\
\hline MELANCIA & MEA \\
\hline MANGA & RX \\
\hline
\end{tabular}

Fonte: Dados da pesquisa. 
Conforme o quadro-síntese anterior, também se pode perceber que na segunda palavra é demonstrada a sonorização (MELANCIA), representada em "M E A", tendo correspondência de som e quantidade de sílaba da palavra que a criança desejou escrever. E "MANGA", mesmo não tendo correspondência de letra, está representada em duas sílabas (MAN = R - GA =X).

\section{Figura 9 - Criança 8}

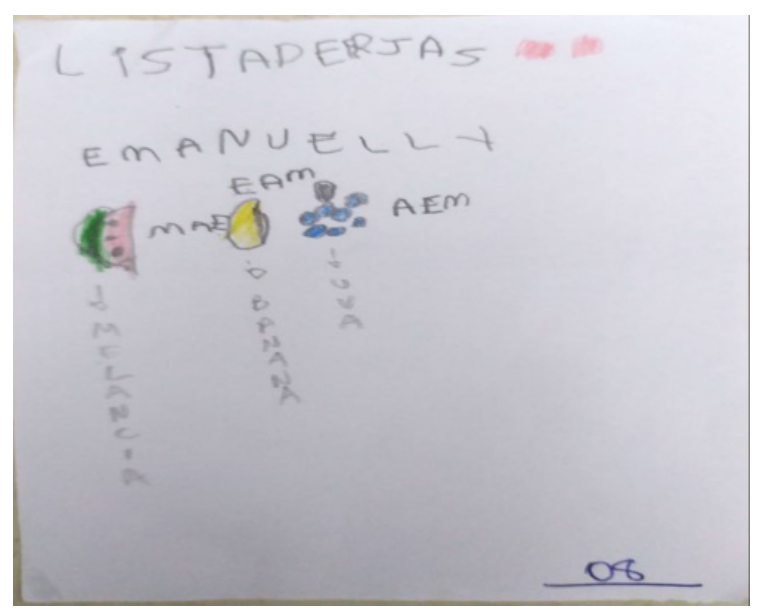

Fonte: Dados da pesquisa.

A Criança 8 não se expressa muito oralmente, mas a sua hipótese na escrita é claramente a pré-silábica. Utiliza-se dos eixos quantitativos e qualitativos. Na análise é necessário destacar alguns pontos: primeiro, ela entendeu que para escrever são necessárias letras; segundo, que necessita de uma quantidade mínima de letras para a palavra ser lida; e terceiro, não é permitido ou não se pode escrever nomes diferentes com letras iguais ou nas mesmas posições. Então veja, a criança utilizou as mesmas letras e a mesma quantidade. Mas observe a inteligência na variação: as letras não ocuparam a mesma posição em nenhuma das palavras representadas: MAE - EAM - AEM. O quadro a seguir permite, de forma mais clara, compreender a hipótese da Criança 8, até mesmo quanto à variação que representou. 


\section{Quadro 8 - Quadro-síntese da Criança 8}

\begin{tabular}{|c|c|}
\hline Frutas favoritas & Como escreveu: \\
\hline MELANCIA & MAE \\
\hline BANANA & EAM \\
\hline UVA & AEM \\
\hline
\end{tabular}

Fonte: Dados da pesquisa.

Figura 10 - Criança 9

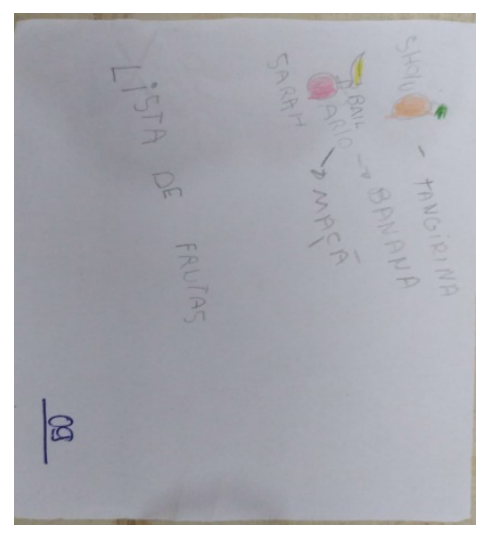

Fonte: Dados da pesquisa.

A Criança 9, como se pode observar, está no segundo período da escrita, ainda na fase pré-silábica, só que ela agora não só diferencia desenho/símbolos de letras, mas as ordenam dentro dos critérios dos eixos quantitativos e qualitativos: primeiro, pela quantidade mínima de letras que julga necessária para a palavra e, em segundo, pela variedade utilizada, pois acredita que para que a palavra possa ser lida ela deve ter uma variedade de letras.

\section{Quadro 9 - Quadro-síntese da Criança 9}

\begin{tabular}{|c|c|}
\hline Frutas favoritas & Como escreveu: \\
\hline TANGERINA & SHOIU \\
\hline BANANA & BAIL \\
\hline MAÇA & ARIO \\
\hline
\end{tabular}

Fonte: Dados da pesquisa. 
A partir do quadro acima, e conforme Ferreiro (2010, p. 27), nesses "[...] dois primeiros períodos, o escrito não está regulado por diferenças ou semelhanças entre os significados sonoros". Entretanto, a expressão espontânea registrada revela grandes avanços do processo escrito da criança. Resta ao docente diagnosticar e trabalhar na perspectiva de alcançar as fases seguintes.

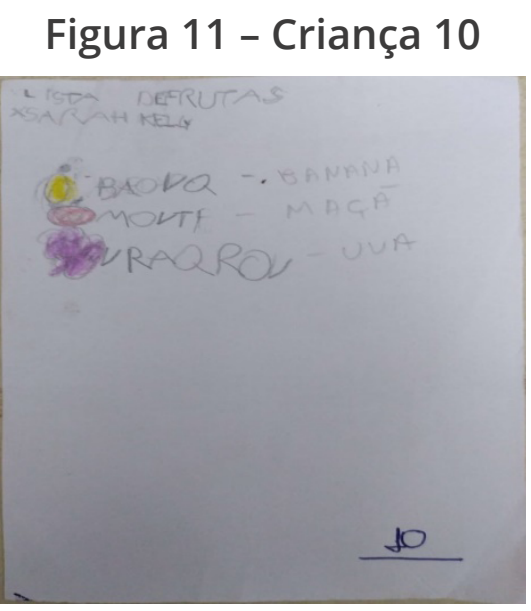

Fonte: Dados da pesquisa.

A Criança 10, assim como a 9, está na mesma hipótese, a présilábica. Com as suposições semelhantes, utiliza-se do critério mínimo de letras (BAOVQ). No mesmo exemplo, pode-se visualizar a variedade que ela usa, pois acredita na mesma, não se pode ler uma palavra com letras iguais, ou próximas.

\section{Quadro 10 - Quadro-síntese da Criança 10}

\begin{tabular}{|c|c|}
\hline Frutas favoritas & Como escreveu: \\
\hline BANANA & BAOVQ \\
\hline MAÇÃ & MOUTF \\
\hline UVA & URAQROU \\
\hline
\end{tabular}

Fonte: Dados da pesquisa. 
É o que Ferreiro e Teberosky (1999) chamam de critérios intrafigurais, que consistem no estabelecimento de atributos necessários de um texto escrito para ser lido e interpretado. Eles se dividem entre os eixos aqui já citados e revelam hipóteses iniciais ricas em detalhes para o melhoramento do trabalho docente. $O$ Quadro 11 serve aqui de síntese para melhor compreensão.

Figura 12 - Criança 11

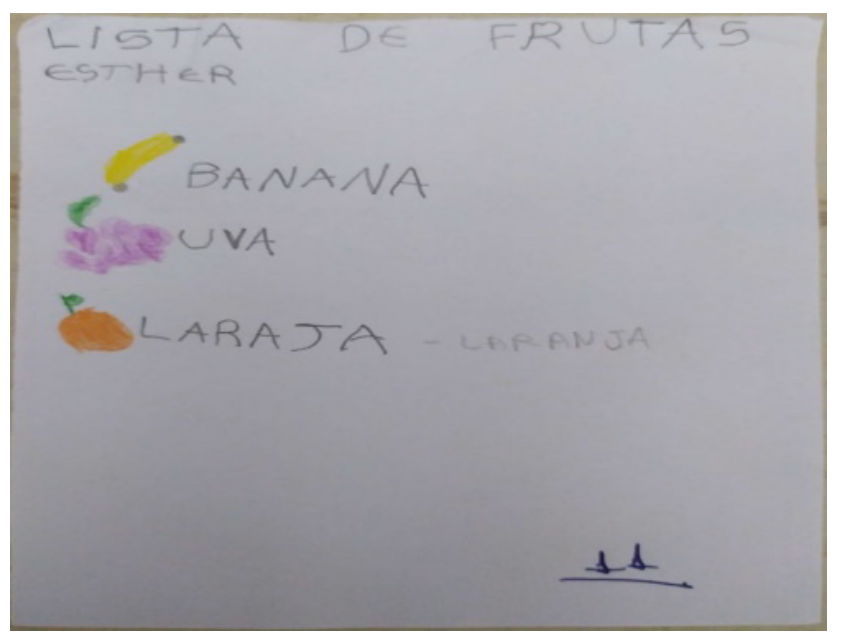

Fonte: Dados da pesquisa.

A Criança 11 surpreendeu e chamou a atenção para a hipótese avançada que se encontra. Conforme se pode observar na sua escrita, a mesma corresponde ao terceiro período, que segundo Figueiredo et al. (2009), é quando se inicia a fonetização da escrita. Nessa fase, faz-se a correspondência entre fala e escrita, e os sinais gráficos se manifestam em suas proposições, emitindo seus valores sonoros.

\section{Quadro 11 - Quadro-síntese da Criança 11}

\begin{tabular}{|c|c|}
\hline Frutas favoritas & Como escreveu: \\
\hline BANANA & BANANA \\
\hline UVA & UVA \\
\hline LARANJA & LARAJA \\
\hline
\end{tabular}

Fonte: Dados da pesquisa. 
Dentro desse período, terceiro e último, têm-se dois níveis. Inicialmente o silábico, que culmina no alfabético, de acordo com Ferreiro (2010). Para Soares (2007) e Figueiredo et al. (2009), ainda nesse período, tem o chamado ortográfico, mas no caso desse discente sua fase é a alfabética, mesmo com o " $\mathrm{N}$ " faltando na palavra "LARANJA". É unânime entre as referidas autoras que esses desvios e possíveis erros são passíveis e comuns na fase.

Figura 13 - Criança 12

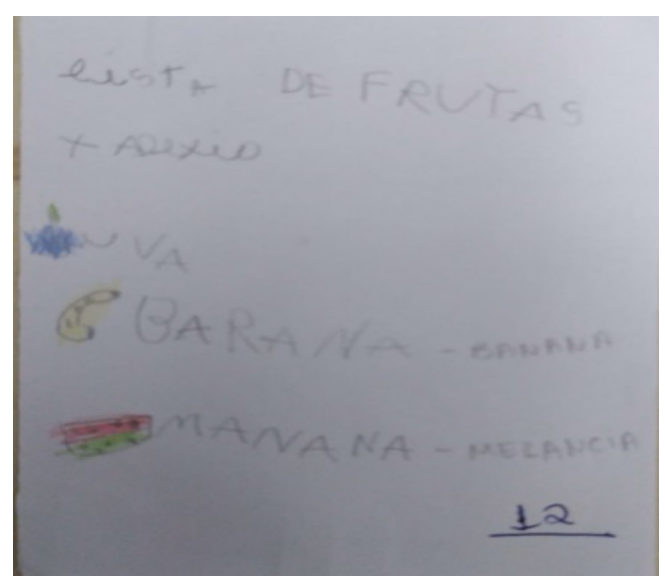

Fonte: Dados da pesquisa.

A Criança 12 está na hipótese silábico-alfabético. Conforme sua escrita, pode-se notar que ela mistura tanto critérios silábicos como critérios alfabéticos (BARANA- MANANA). Há manifestações e indícios claros de conhecimento sonoro dos fonemas, bem como sua construção quase que já convencional, com alguns desvios ou confusões na escrita, como se pode notar na escrita da palavra "MELANCIA".

\section{Quadro 12 - Quadro-síntese da Criança 12}

\begin{tabular}{|c|c|}
\hline Frutas favoritas & Como escreveu: \\
\hline UVA & UVA \\
\hline BANANA & BARANA \\
\hline MELANCIA & MANANA \\
\hline
\end{tabular}

Fonte: Dados da pesquisa. 
Para calçar a mencionada assertiva, e conforme a síntese apresentada no quadro 15, recorre-se a Zorzi (2003) que diz: “[...] o resultado de tal descoberta será uma escrita na qual algumas sílabas já poderão ser representadas por mais de uma letra, aparecendo até mesmo o uso convencional [...]", como pode ser observado no exemplo da Criança 12.

Figura 14 - Criança 13

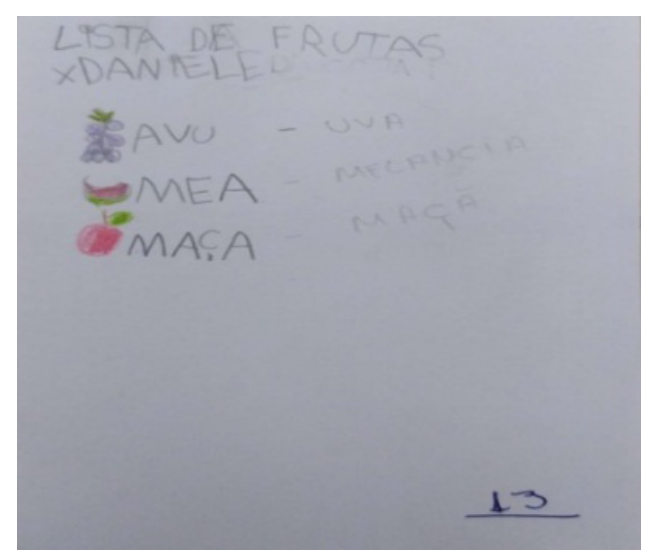

Fonte: Dados da pesquisa.

A Criança 13 está no que se chama de transição silábica para silábica-alfabética. De acordo com sua escrita, percebe-se a representação sonora descrita por Figueiredo et al. (2009, p. 11) como um perfil onde "[...] cada sílaba é representada com algum símbolo ou letras correspondentes (vogal e/ou consoantes)". É o que a autora define como escrita que se aproxima cada vez mais da convencional. Veja como cada sílaba de "MELANCIA" está representada: (MEA). Após a transição, será, conforme o processo de mediação, uma passagem rápida para o nível alfabético final, segundo Ferreiro (2010).

\section{Quadro 13 - Quadro-síntese da Criança 13}

\begin{tabular}{|c|c|}
\hline Frutas favoritas & Como escreveu: \\
\hline UVA & AVU \\
\hline MELANCIA & MEA \\
\hline MAÇ $\tilde{A}$ & MAÇA \\
\hline
\end{tabular}

Fonte: Dados da pesquisa. 
Conforme o quadro de síntese acima, nota-se ainda mais claramente a hipótese demonstrada pela Criança 13. Dessa forma, percebe-se um período transitório já assumindo uma nova hipótese.

Figura 15 - Criança 14

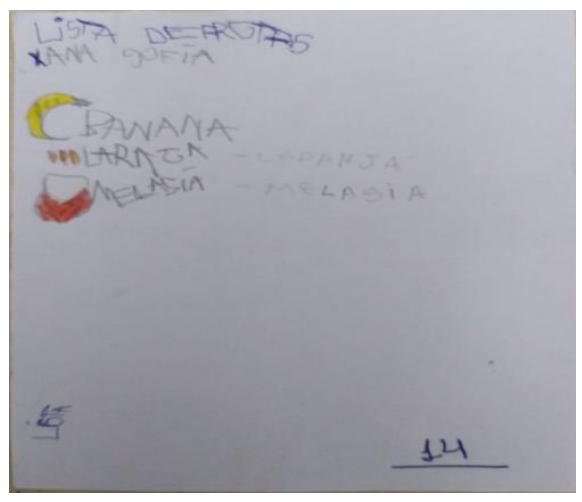

Fonte: Dados da pesquisa.

Nessa transição que perpassou a Criança 14, silábico-alfabético para alfabético, como demonstra a sua escrita acima, a seguinte transformação aconteceu: "[...] a criança descobre que a sílaba não pode ser considerada como uma unidade, mas que ela é, por sua vez, reanalisável em elementos menores" (FERREIRO, 2010, p. 29). Com isso, dá-se entrada no último passo para compreender o sistema socialmente estabelecido.

\section{Quadro 14 - Quadro-síntese da Criança 14}

\begin{tabular}{|c|c|}
\hline Frutas favoritas & Como escreveu: \\
\hline BANANA & BANANA \\
\hline LARANJA & LARAJA \\
\hline MELANCIA & MELASIA \\
\hline
\end{tabular}

Fonte: Dados da pesquisa.

A escrita na hipótese sintetizada no quadro 17 apresenta marcas da oralidade, o que torna comuns os erros, pois segundo Figueiredo et al. (2009, p. 13), "[...] a criança escreve exatamente do 
jeito que fala [...]". O mais interessante nessa fase é observar no dia a dia essa construção, na qual se repetem diversas vezes oralmente no silêncio de suas cadeiras o som da palavra, procurando, com isso, um fonema que corresponda a esse som.

Figura 16 - Criança 15

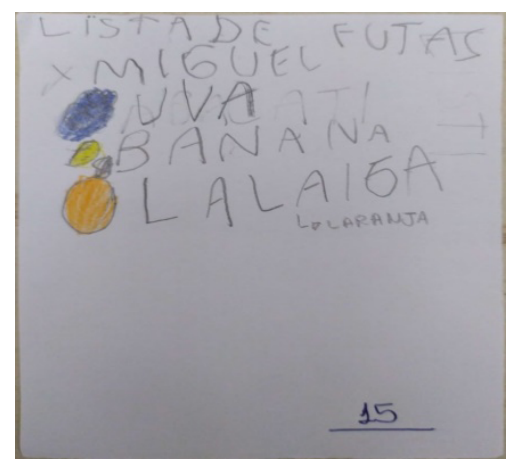

Fonte: Dados da pesquisa.

A Criança 15 é um alfabético claro, pois a escrita já é convencional, com pequenos desvios, o que é comum para o nível uma vez que a escrita nessa fase é uma representação fiel da fala. Nas suas suposições, ela expressa verbalmente e grafa com aquilo que acha corresponder, e que, por vezes, na maioria de suas escritas, correspondem.

Quadro 15 - Quadro-síntese da Criança 15

\begin{tabular}{|c|c|}
\hline Frutas favoritas & Como escreveu: \\
\hline UVA & UVA \\
\hline BANANA & BANANA \\
\hline LARANJA & LALAIGA \\
\hline
\end{tabular}

Fonte: Dados da pesquisa.

Como se pode perceber no Quadro de síntese 15, é nesse sentido a colocação de Zorzi (2003), caracterizando a fase como uma correspondência mais precisa entre sons e letras. Figueiredo et al. (2009, p. 13) colabora quando diz que: "As omissões, trocas e inversões de letras também são comuns nesse nível". É no contato 
com e na interação com a escrita que se vai percebendo que a escrita não é uma reprodução fiel da fala.

Figura 17 - Criança 16

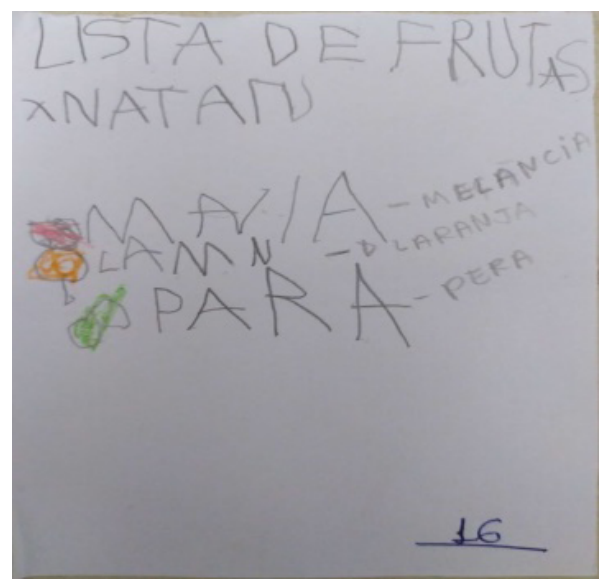

Fonte: Dados da pesquisa.

A Criança 16, conforme se pode observar anteriormente, está na transição silábico para o silábico-alfabético. Isso se justifica na identificação das letras iniciais, critério alfabético de som, e na quantidade de sílabas, ou quase correspondência com a convencional, critério silábico (FIGUEIREDO et al., 2009).

\section{Quadro 16 - Quadro-síntese da Criança 16}

\begin{tabular}{|c|c|}
\hline Frutas favoritas & Como escreveu: \\
\hline MELANCIA & MAIA \\
\hline LARANJA & LAMN \\
\hline PERA & PARA \\
\hline
\end{tabular}

Fonte: Dados da pesquisa.

A transição da Criança 16 se pode perceber no quadro de síntese acima: a fase seguinte, de transição, tem esta marca: junção dos critérios até se chegar à construção sonora, quase convencional da escrita socialmente determinada. Começa-se a perceber que a escrita "[...] pode ser segmentada, ou analisada, em elementos menores, que são os fonemas" (ZORZI, 2003, p. 33). 
Figura 18 - Criança 17

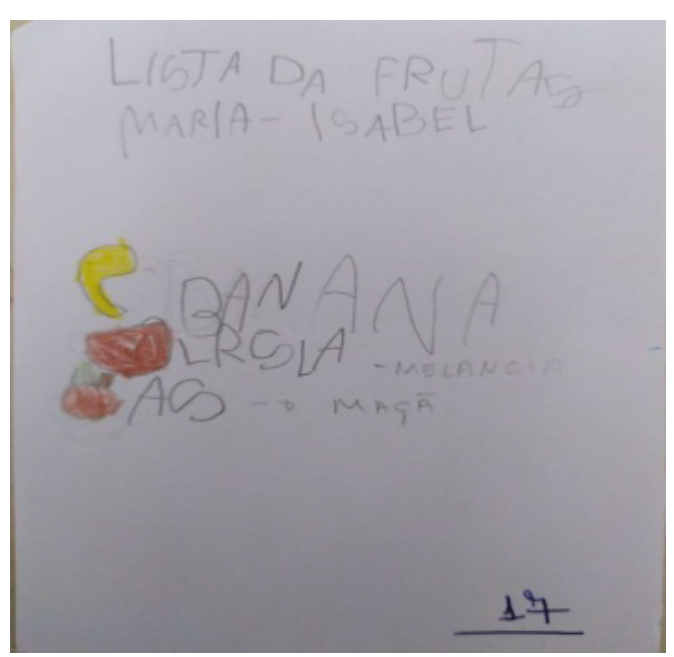

Fonte: Dados da pesquisa.

A Criança 17 demonstra em sua escrita espontânea uma relação entre escrita e fala. A palavra "BANANA" está escrita corretamente, e a palavra "MELANCIA" já tem uma correspondência com a sua sonorização no final. A palavra "MAÇÃ" mescla o som do "S" (=Ç) e do "A". A hipótese aqui presente é a silábica-alfabética. Veja novamente a mistura de critérios silábicos com alfabéticos. Os erros, como já mencionado, sempre serão comuns, principalmente porque aqui já se estabelece relação entre escrita e a fala (FIGUEIREDO et al., 2009).

Quadro 17 - Quadro-síntese da Criança 17

\begin{tabular}{|c|c|}
\hline Frutas favoritas & Como escreveu: \\
\hline BANANA & BANANA \\
\hline MELANCIA & LRSIA \\
\hline MAÇÃ & AS \\
\hline
\end{tabular}

Fonte: Dados da pesquisa.

Dessa feita, pode-se observar que, embora a Educação Infantil seja um espaço onde se nega ou não a alfabetização, há obrigações com esse processo e o letramento. Percebeu-se, por meio dessas escritas espontâneas dos pré-escolares, que muitas hipóteses já são formuladas, e o processo, de fato, inicia-se nesse período, pois 
como prática social, a leitura e a escrita já estão presentes nas vidas dos educandos desde cedo, em seus mais variados ambientes do cotidiano. Assim, é um processo quase natural e uma evolução instantânea.

\section{Algumas considerações}

Este estudo teve por objetivo identificar as hipóteses da escrita nos esboços espontâneos dos pré-escolares em uma turma de Infantil 5 (cinco). Para tanto, anteriormente foram construídas as bases teóricas acerca dos construtos da Teoria da Psicologia Genética de Piaget, teórico que define as fases do desenvolvimento numa perspectiva sequencial, que muito contribuiu para o campo da educação, principalmente no quesito de delimitação das características de cada fase da escrita. Piaget tornou possível ao docente, por meio dessa descrição, delimitar o que a criança pode aprender naquele determinado tempo. Nessa visão, seguiu-se para os questionamentos quanto à alfabetização e letramento na Educação Infantil, conceituando os termos e trazendo alguns questionamentos sobre o tema. Finalizou-se tecendo conceitos de leitura e escrita, e, principalmente, a escrita, por ser o objeto em questão neste estudo.

A pesquisa-ação permitiu visualizar não somente as possibilidades fruto do ambiente alfabetizador, como também revela as potencialidades de, no ambiente da pré-escola, permitir aos alunos vivenciarem e praticarem a escrita, mesmo que espontaneamente, pois é por meio dela que se podem identificar as hipóteses que estão sendo construídas e, com isso, permitir ao docente um trabalho mais sistematizado, no sentido de promover um ambiente direcionado de aprendizagens significativas e, também, efetivas.

Essas questões foram elucidadas na seção anterior, com as escritas e suas devidas interpretações. Nelas, identificou-se as múltiplas e diferentes hipóteses vivenciadas pelas 17 crianças-alvo 
deste estudo, mostrando, com isso, a variedade do processo e características distintas dentro das fases cognitivas que foram identificadas. Os dados descritos mostram as hipóteses dentro dos três grandes períodos, subdivididos em quatro especificamente: pré-silábico; silábico; silábicas-alfabéticas; e alfabéticas. Com relação aos objetivos deste estudo, identificou-se na escrita espontânea as hipóteses dos pré-escolares, mostrando, com isso, a validade não só desses escritos, mas as possibilidades do ambiente alfabetizador na pré-escola.

Valendo-se desses diagnósticos das hipóteses, pode o docente direcionar a sua prática na perspectiva de construir as aprendizagens, conforme o tempo e disposição de cada aluno, o que leva à reflexão de promover esses construtos, no sentido de sensibilizar não só os docentes, que por si só já são demasiadamente atentos, mas também aqueles que delimitam os currículos e as propostas/ projetos escolares municipais para a pré-escola. Nesse sentido, urge discutir a temática em um âmbito maior, envolvendo um público-alvo significativo, com maior amplitude, permitindo assim um diagnóstico da pré-escola com relação às hipóteses da escrita em todos os lócus da cidade.

\section{Referências}

BASTOS, N. M. G. Introdução a metodologia do trabalho acadêmico.

3. ed. Fortaleza (CE), 2005.

BRASIL. Educação Infantil. In: Base Nacional Comum Curricular:

Educação Infantil e Ensino Fundamental. Brasília: MEC/Secretaria de Educação Básica, 2018. Disponível em: http://basenacionalcomum.mec. gov.br/. Acesso em: 22 abril 2019. p. 35-53.

DAVIS, C.; OLIVEIRA, Z. de M. Psicologia na educação. 2.ed. São Paulo: Cortez, 1994.

FERREIRO, E. Reflexões sobre a alfabetização. 2. ed. São Paulo: Cortez, 2010. 
FERREIRO, E.; TEBEROSKY, A. Psicogênese da língua escrita. 2.ed. Porto Alegre, RS: ARTMED EDITORA, 1999.

FIGUEIREDO, R. V.; GOMES, A. L. L.; MELO, C. M. N.; FARIAS, M. C. Q. Avaliação da leitura e da escrita: uma abordagem psicogenética. Fortaleza, CE: Edições UFC, 2009.

GOULART, I. B. Psicologia da educação: fundamentos teóricos aplicações à prática pedagógica. 21.ed. Petrópolis, RJ: Vozes, 2015.

KISHIMOTO, T. M. Alfabetização e letramento/literacia no contexto da educação infantil: desafios para o ensino, para a pesquisa e para a formação. Revista Múltiplas leituras, São Paulo, v. 3, n. 1, p. 18-36, jan. jun. 2010.

KRAMER, S. Alfabetização, leitura e escrita: formação de professores em curso. São Paulo: Editora Àtica, 2004.

\section{LUCAS, M. A. O. F. Os processos de alfabetização e letramento na} educação infantil: contribuições teóricas e concepções de professores. 2008. 322f. Tese (Doutorado em Educação) - Faculdade de Educação, Universidade de São Paulo, São Paulo, 2008.

PINHEIRO, R. C. Multiletramentos e aquisição da leitura e da escrita. Fortaleza, CE: EdUECE, 2019.

SOARES, M. Alfabetização e letramento. 5. ed. São Paulo: Contexto, 2007.

SOARES, M. Letramento: um tema em três gêneros. 3. ed. Belo Horizonte, MG: Autêntica Editora, 2012.

ZORZI, J. L. Aprendizagem e distúrbios da linguagem escrita: questões clínicas e educacionais. Porto Alegre, RS: Artmed, 2003. 